\title{
Evaluation of sE-selectin and sPECAM-1 levels in patients diagnosed with food allergy
}

\author{
Malgorzata Graczyk*, Zbigniew Bartuzi, Michal Przybyszewski, Katarzyna Napiórkowska, Magdalena Zbikowska-Gotz, \\ Jacek Muæka, Ewa Szynkiewicz, Robert Zacniewski, Ewa Socha
}

From Food Allergy and Anaphylaxis Meeting 2011

Venice, Italy. 17-19 February 2011

\section{Introduction}

PECAM-1 (CD31) (Platelet Endothelial Cell Adhesion Molecule-1) is an adhesive molecule found on the side surfaces of endothelial cells and blood platelets, taking part in the cell adhesion processes. Adhesive molecules are known to play an important part in the inflammatory processes, including inflammations with allergic background. The goal of the study was to assess the sEselectin and sPECAM-1 levels in patients diagnosed with food allergies.

\section{Materials and Methods}

80 patients were enrolled in the study, including 50 patients with food allergy and accompanying stomach pains, and 30 patients with dyspeptic discomfort without underlying food allergy. All subjects were subjected to gastroscopic examination, gastric mucosa biopsy for histopathological evaluation, including the presence of eosinophils in the inflammatory infiltrates, and assessment of Helicobacter pylori colonization status. Blood was collected from each subject for determination of the serum levels of the E-selectin and PECAM-1 adhesive molecules. sPECAM-1 and sE-selectin determinations were performed in a Bender MedSystems ELISA assay.

\section{Results}

The average sE-selectin levels in the food allergy patient population were $54.0+/-21.6 \mathrm{ng} / \mathrm{mL}$, while in the allergy-free population, the average sE-selectin levels were $57.7+/-17.9 \mathrm{ng} / \mathrm{mL}$. No statistically significant difference between $\mathrm{sE}$-selectin levels was found between food allergy patients and patients with dyspeptic symptoms without concomitant food allergy (Mann-Whitney

\footnotetext{
Collegium Medicum in Bydgoszcz, Department of Allergology, Clinical
} Immunology and Internal Diseases, Bydgoszcz, Poland
U-test, $\mathrm{p}=0.453028$ ). In the food allergy patient population, average sPECAM-1 levels were $132.8+/-31.4 \mathrm{ng} /$ $\mathrm{ml}$, while in the allergy-free population average sPECAM-1 levels were $139.6+/-31.1 \mathrm{ng} / \mathrm{ml}$. The analysis of the obtained results revealed no statistically significant difference between sPECAM-1 levels in food allergy patients and patients with dyspeptic symptoms without concomitant food allergy.

\section{Conclusions}

The results of examinations conducted in this study showed no statistically significant differences in serum PECAM-1 and E-selecine levels between the study groups.

Published: 12 August 2011

doi:10.1186/2045-7022-1-S1-P69

Cite this article as: Graczyk et al:: Evaluation of sE-selectin and SPECAM-

1 levels in patients diagnosed with food allergy. Clinical and Translational Allergy 2011 1(Suppl 1):P69.

Submit your next manuscript to BioMed Central and take full advantage of:

- Convenient online submission

- Thorough peer review

- No space constraints or color figure charges

- Immediate publication on acceptance

- Inclusion in PubMed, CAS, Scopus and Google Scholar

- Research which is freely available for redistribution

Submit your manuscript at www.biomedcentral.com/submit
C Biomed Central

(c) 2011 Graczyk et al; licensee BioMed Central Ltd. This is an open access article distributed under the terms of the Creative Commons Attribution License (http://creativecommons.org/licenses/by/2.0), which permits unrestricted use, distribution, and reproduction in any medium, provided the original work is properly cited. 